\title{
PERANAN MODEL PEMBELAJARAN KOOPERATIF TIPE ROOL PALYING MENGGUNAKAN SISTEM PENCERNAAN MAKANAN PADA MANUSIA DI KELAS XI IPA SMA NEGERI 9 KOTA AMBON
}

\author{
Ali Awan \\ Program Studi Pendidikan Biologi FKIP Unpatti Ambon \\ Email: aliawanprof@gmail.com
}

\begin{abstract}
Background: Cooperative Learning is a learning model that can enable students. Students are encouraged to work together in certain activities so that students are required to share information with other students and learn from each other. In cooperative learning, students are divided into groups of two or more. One model of cooperative learning is a cooperative learning model of Rool playing type. Method: This research was conducted in January 2015-February 2015. The research method used is classroom action research method (PTK). Collecting technique of data in the form of test result of learning done before and after teaching activity finished. The instrument used is a multiple choice learning test with 5 options of 30 items. The population in this study is the entire class XI IPA SMA Negeri 9 Ambon City which consists of 3 classes. Of the 3 population classes, two classes were used as a sample, namely class XI IPA 2 as the experimental class, and XI IPA 1 as the control class.

Result: The experimental class using the cooperative learning model of Rool playing type has pretest averages $=11,31$, posttest $=27,08$ and control class using direct learning model has pretest average $=12,22$, posttest $=22,91$. The results showed that there is an increase in student learning outcomes using cooperative learning model type Rool playing using the concept of digestive system in humans in class XI IPA SMA Negeri 9 Ambon City.

Conclusion: There is an improvement of learning outcomes of students whose learning process using cooperative learning model of think talk write type on Human Excretion System concept in class XI IPA SMA Negeri 9 Kota Ambon.
\end{abstract}

Keywords: cooperative learning model, Rool Playing, digestive system in humans.

\begin{abstract}
Abstrak
Latar Belakang: Cooperatif Learning merupakan suatu model pembelajaran yang dapat mengaktifkan siswa. Siswa didorong untuk melakukan kerja sama dalam kegiatan-kegiatan tertentu sehingga siswa dituntut untuk berbagi informasi dengan siswa lainnya dan saling belajar sesama mereka. Dalam pembelajaran kooperatif, siswa dibagi menjadi beberapa kelompok yang terdiri dari dua orang atau lebih. Salah satu model pembelajaran kooperaif adalah model pembelajaran koopertif tipe Rool playing. Metode: Penelitian ini dilaksanakan pada bulan Januari 2015-Pebruari 2015. Metode penelitian yang digunakan adalah metode penelitian tindakan kelas (PTK). Teknik pengumpuland data berupa tes hasil belajar yang dilakukan sebelum dan sesudah kegiatan belajar mengajar selesai. Instrumen yang digunakan adalah tes hasil belajar yang berbentuk pilihan ganda dengan 5 options sebanyak 30 butir soal. Populasi dalam penelitian ini adalah seluruh kelas XI IPA SMA Negeri 9 Kota Ambon yang terdiri dari 3 kelas. Dari 3 kelas populasi, digunakan 2 kelas sebagai sampel yaitu kelas XI IPA 2 sebagai kelas eksperimen, dan XI IPA 1 sebagai kelas kontrol.

Hasil: Kelas eksperimen yang menggunakan model pembelajaran kooperatif tipe Rool palying memiliki rata-rata pretest $=11,31$, posttest $=27,08$ dan kelas kontrol yang menggunakan mdel pembelajaran langsung memiliki rata-rata pretest $=12,22$, posttest $=22,91$. Hasil penelitian menunjukkan bahwa ada peningkatan hasil belajar siswa yang menggunakan mdel pembelajaran kooperatif tipe Rool playing menggunakan konsep sistem pencernaan pada manusia di kelas XI IPA SMA Negeri 9 Kota Ambon. Kesimpulan: Terdapat peningkatan hasil belajar siswa yang proses pembelajarannya menggunakan model pembelajaran kooperatif tipe think talk write pada konsep Sistem Ekskresi Manusia di kelas XI IPA SMA Negeri 9 Kota Ambon.
\end{abstract}

Kata Kunci: model pembelajaran kooperatif, Rool Playing, sistem pencernaan makanan pada manusia. 


\section{PENDAHULUAN}

Kualitas pendidikan merupakan faktor penting yang dapat berpengaruh terhadap kualitas pembelajaran di sekolah yang akan meningkatkan penguasaan dan pemahaman terhadap konsep serta teknologi yang harus dimiliki siswa. Hal tersebut menuntut para pelaku pendidikan, terutama para guru untuk lebih kreatif dan inovatif dalam proses pembelajaran di kelas.

Berdasarkan hasil observasi dan wawancara dengan guru Biologi SMA Negeri 9 Kota Ambon, dalam proses pembelajaran Biologi di kelas, guru umumnya menerapkan metode ceramah. Metode ini menyebabkan siswa cepat jenuh. Kejenuhan siswa dapat dilihat dari banyaknya siswa yang kurang memperhatikan guru pada saat guru mengajar dan siswa cenderung pasif. Hal ini menyebabkan kemampuan pamahaman siswa dalam pembelajaran Biologi kurang, sehingga hasil belajar siswa kurang memuaskan. Untuk meningkatkan hasil belajar siswa, perlu adanya pengembangan dalam proses pembelajaran Biologi, sehingga tidak terkesan hanya mentransfer ilmu pengetahuan kepada siswa saja, tetapi juga membantu siswa membentuk pengetahuan serta memberdayakan mereka untuk mampu memecahkan masalah yang dihadapi.

Agar tujuan pembelajaran dapat dicapai dengan maksimal, dalam proses pembelajaran guru hendaknya menerapkan model pembelajaran. Cooperatif Learning merupakan suatu model pembelajaran yang dapat mengaktifkan siswa. Siswa didorong untuk melakukan kerja sama dalam kegiatan-kegiatan tertentu sehingga siswa dituntut untuk berbagi informasi dengan siswa yang lainnya dan saling belajar mengajar sesama mereka. Dalam pembelajaran kooperatif, siswa dibagi menjadi beberapa kelompok yang terdiri dari dua orang atau lebih. Salah satu model pembelajaran kooperaif adalah model pembelajaran koopertif tipe Rool playing. Model pembelajaran yang diperkenalkan oleh Huinker dan Laughlin ini pada dasarnya dibangun melalui kegiatan berpikir, berbicara dan menulis. Siswa diminta membaca, membuat catatan kecil, menjelaskan, mendengar, membagi ide bersama teman dalam kelompok, kemudian bermain peran sesuai dengan tugas yang dibebankan kepada masing-masing siswa. Dengan model pembelajaran kooperatif ini, siswa dapat belajar bukan hanya dari guru tetapi juga dari sesama anggota kelompoknya, sehingga diharapkan siswa dapat meningkatkan minat, dan aktivitas belajarnya.

\section{METODE}

Model yang digunakan dalam penelitian ini adalah penelitian tindakan kelas (PTK). Populasi dalam penelitian ini adalah seluruh kelas XI IPA SMA Negeri 9 Kota Ambon Tahun pelajaran 2014/2015 sebanyak 3 kelas yang berjumlah 106 orang siswa. Sampel yang digunakan dalam penelitian ini sebanyak 2 kelas yaitu kelas XI IPA 1 sebagai kelas eksperimen dan kelas XI IPA 2 sebagai kontrol. Penelitian menggunakan siklus, dengan Desain penelitian yang dilakukan adalah pre test-post control group design. Menurut Sugiyono (2010:112): Rancangan: $\mathrm{R} \mathrm{O}_{1} \times \mathrm{O}_{2} ; \mathrm{R}_{3} \mathrm{O}_{4}$

Dalam disain ini terdapat dua kelompok yang dipilih secara random, kemudian diberi pre test (tes awal) dengan soal yang telah di uji validitas dan reliabilitas. Selanjutnya untuk mengetahui ada tidaknya pengaruh perlakuan, diberikan post test (tes akhir) pada kedua kelas tersebut.

Instrumen yang digunakan dalam penelitian ini adalah tes hasil belajar siswa pada konsep Sistem Pencernaan pada Manusia. Tes berupa pilihan ganda dengan 5 (lima) option dengan jumlah 50 soal. Penelitian ini dilakukan pada siswa kelas XI IPA SMA Negeri 9 Kota Ambon semester pertama tahun pelajaran 2014/2015.

\section{HASIL DAN PEMBAHASAN Hasil Penelitian}

Dari Hasil penelitian yang dilakukan di SMA Negeri 9 Kota Ambon menunjukkan bahwa ada peningkatan dan perbedaan hasil belajar siswa di kelas XI IPA 2 (kelas eksperiem) yang proses pembelajarannya menggunakan model pembelajaran kooperatif tipe Rool Playing dan dikelas XI IPA 1 (kelas kontrol) yang proses pembelajarannya menggunakan model pembelajaran langsung. 
Dapat dijelaskan skor rata-rata pre test, post test dan $\mathrm{N}$-gain belajar siswa kelas kontrol dan kelas eksperimen. Berdasarkan diagram tersebut dapat diketahui bahwa rata-rata skor pre test di kelas yang proses pembelajarannya menggunakan proses pembelajaran kooperatif tipe Rool Playing (kelas eksperimen) adalah 11,31 dengan skor rata-rata post test 27,08. Sedangkan untuk kelas yang proses pembelajarannya menggunakan proses pembelajaran langsung rata-rata skor pretest 12,22 , dan rata-rata skor post test 22,91. Rata-rata skor pre test di kelas eksperiemn dan kelas kontrol tidak jauh berbeda, sedangkan ratarata skor post test di kelas eksperimen lebih tinggi dibandingkan dengan rata-rata skor post test di kelas kontrol.

\section{Pembahasan}

Proses pembelajaran di kelas kontrol menggunakan model pembelajaran langsung, dimulai dengan guru menyampaikan materi secara langsung kepada siswa. Setelah selesai menyampaikan materi, guru kemudian membimbing siswa untuk interaksi Tanya jawab apabila peserta didik mengalami kesulitan dalam memahami materi yang disampaikan. Selanjutnya guru memberikan kesimpulan. Dalam proses kegiatan belajar mengajar di kelas kontrol, siswa cenderung pasif karena hanya mendengar dan menerima semua informasi dari guru saja, sedangkan siswa tidak berperan dalam pembentukan pengetahuannya sendiri, sehingga siswa cepat merasa bosan dan kurang termotivasi untuk mengikuti pelajaran yang disampaikan guru.

Model pembelajaran kooperatif tipe Rool Playing diawali dengan tahap bermain peran, pada tahap ini setiap siswa membaca dan mempelajari topic yang diberikan oleh guru sesuai dengan perannya. Kemudian setelah membaca setiap siswa membuat catatan hasil bacaan dengan bahasa mereka sendiri. Tahap selanjutnya adalah menelaah hasil perannya pada diskusi kelompok dengan teman satu kelompoknya untuk membahas isi catatan yang telah mereka buat. Pada tahap ini siswa mengeluarkan pendapat, dan mencoba mencari jawaban dari hal-hal yang kurang mereka pahami yang ditemukan dalam topik masing-masing dipresentasikan. Dalam kegian presentasi terjadi diskusi dalam kelas, antara kelompok yang melakukan presentasi dan kelompok yang lain.

Model pembelajaran kooperatif tipe Rool Playing lebih dapat meningkatkan hasil belajar siswa dibandingkan dengan mdel pembelajaran langsung, karena dalam proses pembelajarannya siswa yang biasa tidak aktif menjadi lebih aktif sebab mereka dituntut untuk menguasai dan mengembangkan kemampuan dalam dirinya pada materi yang sedang dipelajari. Selain itu siswa, dapat berinteraksi dengan siswa lain dengan bertanya, bermain peran serta mengeluarkan pendapat sehingga suasana belajar menjadi lebih hidup dan menyenangkan. Dengan susunan pembelajaran yang menyenangkan siswa lebih termotivasi belajar baik secara individu maupun kelompok.

\section{SIMPULAN}

Berdasarkan hasil penelitian ini maka terdapat peningkatan hasil belajar siswa yangproses pembelajarannya menggunakan model pembelajaran kooperatif tipe think talk write pada konsep Sistem Ekskresi Manusia di kelas XI IPA SMA Negeri 9 Kota Ambon.

\section{DAFTAR PUSTAKA}

Arikunto, Suharsimi. (2010). Prosedur Penelitian Suatu Pendekatan Praktik. Jakarta: PT. Rineka Cipta.

Sudjana, Nana. (2011). Dasar-dasar Proses Belajar Mengajar. Bandung: Sinar Baru Algensindo.

Sugiyono. (2009). Metode Penelitian Kuantitatif, Kualitatif dan $R$ \& $D$. Bandung: CV. Alfabeta.

Suprijono, Agus. (2012). Cooperatif Learning. Yogyakarta: Pustaka Pelajar.Suyatno. (2009). Menjelajah Pembelajaran Inovatif. Sidoarjo: Masmedia Buana Pustaka. 